\title{
Multiple-perspective Reorganisation of the Dairy sector: Mathematical Programming Approach
}

\author{
Tina Kocjančič, Jaka Žgajnar, Luka Juvančič \\ Biotechnical Faculty of the University of Ljubljana, Slovenia
}

\begin{abstract}
Background: Agriculture is a production system in which the economic principles of organisation act in mutual dependence with its ecological boundaries. Objectives: Building on this premise, the paper evaluates performance of a chosen agricultural production system (dairy production in Slovenia) from two complementary perspectives, the socio-economic and the biophysical. Methods/Approach: The latter is presented by means of emergy analysis, which is a system-based approach that measures the aggregate work of biosphere needed for the provision of goods or services in the units of solar energy joules. The novelty aspect of this paper is the introduction of emergy indicators into the standard socioeconomic optimisation model of the chosen agricultural production system. The optimisation model based on linear mathematical programming is designed to empirically investigate different alternatives to the sector's reorganisation. Results: The results of the optimisation models suggest considerable restructuring of the sector and, consequently, large discrepancies in the sector's performance. Conclusions: The results suggest that further expansion of organic production systems as a result of a stronger environmental focus in farm management would improve the sector from both, the socio-economic and the emergy perspective. Moreover, even pursuing certain socio-economic targets may improve the sector's biophysical performance and lower pressure on the local environment.
\end{abstract}

Keywords: agriculture, dairy sector, system approach, mathematical programming, emergy analysis,

JEL classification: C61, Q5, Q10

Paper type: Research article

Received: Feb 15, 2016

Accepted: Aug 25, 2016

Citation: Kocjančić, T., Žganjar, J., Juvančić, L. (2016), "Multiple-perspective reorganisation of a dairy sector: mathematical programming approach", Business Systems Research, Vol. 7, No. 2, pp. 35-48.

DOI: 10.1515/bsrj-2016-0011

\section{Introduction}

Agriculture is a production system where the economic principles of organisation act in mutual dependence with its ecological boundaries (Smith et al., 2000; OECD, 2000; van Zanten et al., 2014). The mutual connectedness of agriculture with its local 
and global environment and the risks related to high complexity of their interactions may be understood as a source of increasing challenges that the agriculture is facing today.

On the other hand, a complex and often conflicting array of challenges that agriculture is facing (eg. diminishing production resources, volatile market conditions, production- and market-associated risks, environmental depletion) calls for a restructuring of the sector in terms of competitiveness and productivity improvements, taking full account of the requirements of sustainable development (Godfray et al., 2010; OECD/FAO, 2012). Various objectives of the common agricultural policy and an increased demand for interdisciplinary research approaches had an important role in the development of bio-economic models. These are in general known as (mathematical) models that link different disciplines in order to answer multi-dimensional questions about the organisation of agricultural production systems (Flichman et al., 2012). Bio-economic models as analytical tools that support the decision-making process need to embrace comprehensive economic evaluation with the limitations and requirements of the natural environment (Daily et al., 2000). However the integration of biophysical and economic components in technical and conceptual sense still remains the most significant challenge in this field (Flichman et al.,2012; Gasparatos et al. 2009, Gasparatos et al.,2012).

Emergy analysis (Odum, 1983, 1988, 1996) is a system-based environmental accounting approach that measures the aggregate work of biosphere needed for provision of any good or service. Based on a biophysical understanding of value, the analysed processes are broken down into the stocks and flows of natural capital invested in the production and quantified in physical units, solar energy joules (seJ). As such to define and quantify the contribution of ecological processes in the production of any good or service. In contrast with the conventional economic evaluation, which is anthropocentric in its nature with commonly rather reductionist viewpoint, emergy analysis provides a system based eco-centric perspective on agricultural activity (Brown et al., 2004, 2010, Odum 1988, 1996). The emergy approach has been extensively used to investigate several different agricultural systems, either at a farm (La Rosa et al., 2008; Hu et al., 2012), provincial/regional (Li et al., 2012; Ghisellini et al., 2013) or national level (Rydberg et al., 2006; Chen et al., 2006). It has been successfully implemented to evaluate and compare biophysical functioning of alternative production systems, that differ either in the type of agricultural activity (Lefroy et al., 2003), in production technology (Castellini et al., 2006; La Rosa et al., 2008), or have different spatial or time-scale (Chen et al., 2006; Vigne et.al., 2013). A comparison of emergy and economic characteristics of systems investigated is less common (e.g. Lu et al., 2010; de Barros et al., 2009), but often recognised as a complementary approach that provides additional information needed for a more comprehensive perspective on agricultural performance (Jaklic et.al., 2014).

With the ambition to improve the quality of decision-making processes in agriculture by applying a more complete perspective, this paper attempts to incorporate emergy indicators into standard socioeconomic optimisation models. This is illustrated by investigating performance of a chosen agricultural production system from multiple perspectives and taking into account various sets of optimisation criteria. More specifically, the paper builds on the case of dairy production in Slovenia. Dairy production is chosen as it presents a case of a complex agricultural production system. In terms of the sector's relevance for the country studied, dairy production is the predominant sector in Slovenian agriculture that 
contributes the most towards the national agricultural output. By the same token, dairy sector is also the largest single consumer of natural resources available in the country. In the last decade the sector has undergone massive (mainly economically driven) restructuring. The number of dairy farms has decreased substantially, those remaining in the sector mainly increased the herd size, specialised and modernised their production. Despite the overall productivity and quality improvement of the country's dairy sector, the aggregate quantity of production remained largely unchanged.

The paper is organised as follows. The section 'Material and methods' describes the steps and procedures applied in the empirical analysis of the structure and performance of dairy production in Slovenia. The sector is disaggregated into nine farm types, representing the variety of the production systems in the country. The section continues with theoretical specification of the optimisation model and outlines the optimisation criteria (socio-economic- and emergy-related). In order to link the main findings with their (policy, research) implications, the 'Results and discussion' are treated together in one section.

\section{Material and methods}

\section{Methodological approach- schematic representation}

The mathematical modular tool aimed to investigate Slovenian dairy sector was developed in two stages. The methodological approach is schematically represented in Figure 1. Firstly, in a preliminary analysis Slovenian dairy farms were broken down into nine 'typical' production types that were further evaluated from socio-economic and biophysical (emergy based) perspective. By farms' reaggregation, the model of the dairy sector in 2010 was specified. With its characteristics (farm, production structure, economic and biophysical emergy performance) it served as a baseline reference to the model solutions obtained from the optimisation model developed.

Figure 1

Schematic Representation of the Methodological Approach

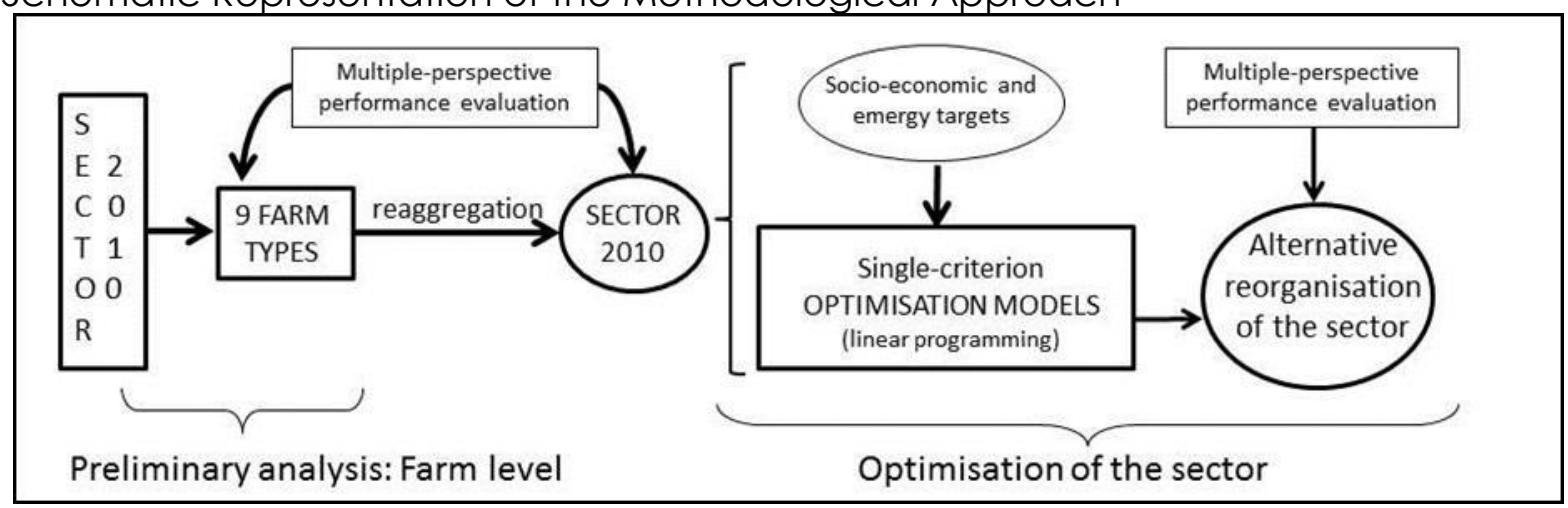

Source: Author's illustration

The development of the optimisation model at the national level represents the central focus of the research presented in the paper. The model is based on linear programming paradigm and served as a supportive tool to investigate various alternatives to sector's reorganisation pursuing a single optimisation criterion (e.g. income, production, system sustainability). It also served to determine the optimal (min/max) values/characteristics that the sector can potentially reach under each 
optimisation scenario. Finally, the model solutions were evaluated, compared and positioned according to their performance in socio-economic and emergy terms.

\section{Preliminary analysis of model farm types}

In a preliminary analysis the farms engaged in dairy production in Slovenia were categorised into nine production types. These represent the diversity of farm types engaged in dairy production in Slovenia. They range from subsistence producers (FT1), to semi-subsistence oriented farms (FT2), and a limited, but growing number of organic producers, varying in production intensity and in the degree of market presence (FT3 and FT4). The conventional production systems are prevailing, although they significantly differ in several parameters, such as herd size, choice of breeds, size and structure of utilised agricultural area, and the quantity and origin of compound feed (FT5 to FT9). Basic farm characteristics (Table 1) that derived from the Agricultural Census 2010 performed by Statistical office of Slovenia and from the Central Cattle Breeding database from Agricultural institute of Slovenia were used for describing production resources, technological and economic parameters of each farm type, and to quantify key human-controlled and environmental outputs and input flows to the dairy production systems.

Table 1

Basic Farm Type Characteristics (year 2010)

\begin{tabular}{|c|c|c|c|c|c|c|c|c|c|}
\hline & FT1 & FT2 & FT3 & FT4 & FT5 & FT6 & FT7 & FT8 & FT9 \\
\hline $\begin{array}{l}\text { farm } \\
\text { type }\end{array}$ & $\begin{array}{l}0 \\
0 \\
\frac{1}{0} \\
0 \\
\frac{.0}{n} \\
\frac{0}{2} \\
\text { un }\end{array}$ & 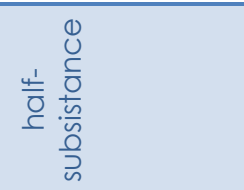 & 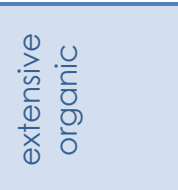 & 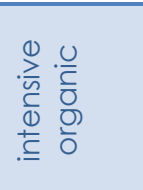 & 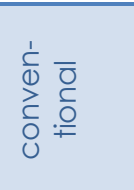 & 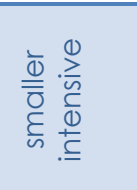 & 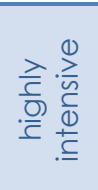 & 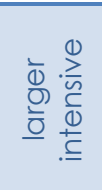 & 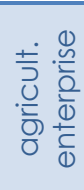 \\
\hline Breed* & $S, B S$ & $S, B S$ & $S, B S$ & $S, B S$ & $S, B S$ & $\begin{array}{l}\mathrm{HF}, \mathrm{S} \\
\mathrm{BS}\end{array}$ & $\mathrm{HF}$ & $\mathrm{HF}$ & $\mathrm{HF}$ \\
\hline $\begin{array}{l}\text { Dairy } \\
\text { cows }\end{array}$ & 2 & 8 & 4 & 26 & 20 & 46 & 51 & 105 & 654 \\
\hline $\begin{array}{l}\text { Milk } \\
\text { yield** }\end{array}$ & 3,600 & 4,500 & 3,000 & 4,500 & 5,500 & 7,400 & 9,300 & 7,500 & 7,000 \\
\hline UAA*** & 4 & 9 & 9 & 44 & 17 & 37 & 37 & 90 & 762 \\
\hline $\begin{array}{l}\text { crop } \\
\text { area }\end{array}$ & $11 \%$ & $19 \%$ & $8 \%$ & $13 \%$ & $37 \%$ & $56 \%$ & $59 \%$ & $53 \%$ & $58 \%$ \\
\hline terrain & steep/ hilly & steep/ hilly/ flat & steep/ hilly & hilly/flat & hilly/flat & hilly/flat & flat & flat & flat \\
\hline
\end{tabular}

Several socioeconomic and emergy performance indicators were calculated. These provided an insight into the differences between the farm types' in their profitability, productivity and farmer's income independence and environmental impact of the production (socioeconomic indicators), as well as biophysical efficiency, system's sustainability and utilisation of local resources (emergy indicators). A more detailed insight to the methodology, selected indicators and the results of the preliminary analysis can be found in Jaklič et al (2014).

\section{Definition of the optimisation modelling tool at the national level}

In the subsequent step of the analysis, the status of the dairy sector in 2010 was reconstructed from the nine farm types identified in the preliminary analysis. The main specifications of the sector, such as the structure of the sector, total production, income, number of animals and intensity of production, as well as various socio-economic and biophysical performance characteristics were 
identified. The model of the sector in 2010 provided a reference and a baseline for the development of the optimisation model, formulated to look for an optimal (farm) structure of the sector that will satisfy the particular objective(s).

The optimisation modelling tool is supported by different single-criteria models based on linear mathematical programming (LP). LP is defined as a maximisation or minimisation of a single linear objective function ( $r$ for maximisation and $k$ for minimization) with a feasible area of solutions that is determined by a set of linear constraints. This is mathematically represented as:

$\max Z_{r}=\sum_{q=1}^{Q} c_{r q} x_{q} \quad$ for all $r=1$ to $n$

s.t.

$\sum_{q=1}^{Q} a_{i q} x_{q} \leq b_{i} \quad$ for all $i=1$ to $m$

$x_{q} \geq 0$

$\min Z_{k}=\sum_{q=1}^{Q} c_{k q} x_{q} \quad$ for all $k=1$ to $t$

s.t.

$\sum_{q=1}^{Q} a_{i q} x_{q} \leq b_{i} \quad$ for all $i=1$ to $m$

$x_{q} \geq 0$

where $Z$ is an objective function, $r$ is an index that defines the objectives that are subject to maximisation (1.1) and $k$ for the ones that are minimised (1.2), $x_{q}$ are decision variables that in our study represent a number of farms within each farm type (Table 1), where $q$ is an index that determines a farm type and $Q$ is a total number of farm types, $c_{q}$ are an objective function coefficients and $a_{i q}$ technical coefficients of each farm type. A set of constraints that restricts the values that may be assumed by decision variables is represented by $b_{i}$.

The number of dairy farms within each farm type $x_{q}$ denotes a key model variable and the original model solution. This solution that directly indicates a structure of the sector, indirectly determines values of other characteristics of the sector, such as an average farm size, number of animals, land structure, soil eroded, structure of natural resource use etc.

The model includes set of constraints $\left(b_{i}\right)$ that present the sector's boundaries that are defined by agricultural land intended for dairy production in 2010 and remain fixed through the entire modelling process. Furthermore, the problem of transition between different farm types is considered by incorporating additional constraints. These describe the possibility of the reorganisation of one type of a farm into another, taking into consideration the comparability and differences in farming conditions between the types, such as larger discrepancies in their size, terrain on which farms are located and production technology. 
The objectives $(r, k)$ applied in the models relate to farm and sector level indicators of socio-economic and emergy based performance. Socioeconomic performance focuses on objectives related to income of a farmer and the sector, productivity and employment, public payments and global environmental impact. Emergy criteria on the other hand pursue biophysical efficiency and intensity of emergy use, pressure on local environment and sustainability of the production system. The objectives are listed and shortly described in Table 2.

Table 2

Socio-economic and emergy-related objectives simulated in single-criteria optimisation models

\begin{tabular}{|c|c|c|}
\hline \multicolumn{2}{|c|}{ Socioeconomic indicators / objectives } & \multirow{2}{*}{$\begin{array}{l}\operatorname{Max} \mathbf{Z}_{\mathrm{r}} / \min \mathbf{Z}_{\mathrm{k}} \\
\operatorname{Max} I N C\end{array}$} \\
\hline Income & $\begin{array}{l}\text { Total income in the sector is the aggregated income of } \\
\text { dairy farms }\end{array}$ & \\
\hline & $\begin{array}{l}\text { Hourly wage is income received per hour of labour (PP } \\
\text { incl.) }\end{array}$ & Max HW \\
\hline \multirow[t]{2}{*}{ Productivity } & $\begin{array}{l}\text { Total production of the sector is derived by weighting and } \\
\text { adding-up of the production of dairy farms }\end{array}$ & $\operatorname{Max} Q$ \\
\hline & $\begin{array}{l}\text { Intensity of production defined in terms of the annual yield } \\
\text { of the milk per cow }\end{array}$ & Max INT \\
\hline Employment & $\begin{array}{l}\text { Number of employed persons ( } 1 \text { person equals } 2000 \\
\text { working hours) }\end{array}$ & Max EMPL \\
\hline \multirow[t]{2}{*}{ Public payments } & Total amount of public payments (PP) & Min PP \\
\hline & $\begin{array}{l}\text { Dependence of PP is defined as share of PP in farm's } \\
\text { income }\end{array}$ & Min \%PP \\
\hline \multirow[t]{2}{*}{ Environmental impact } & Total GHG emissions of total sector's production & Min GHG \\
\hline & $\begin{array}{l}\text { Relative burden of GHG is defined as emissions released } \\
\text { per unit of production }\end{array}$ & Min GHG/Q \\
\hline \multicolumn{3}{|c|}{ Emergy indicators / objectives } \\
\hline $\begin{array}{l}\text { Biophysical efficiency and } \\
\text { intensity of emergy use }\end{array}$ & $\begin{array}{l}\text { Unit Emergy Value (UEV) indicates biophysical efficiency of } \\
\text { a system in emergy use and renewability of a system } \\
\text { Emergy Density (ED) is emergy per hectare and denotes } \\
\text { emergy use intensity }\end{array}$ & $\begin{array}{l}\text { Min UEV } \\
\text { Max ED }\end{array}$ \\
\hline $\begin{array}{l}\text { Exploring renewable local } \\
\text { resources and system } \\
\text { sustainability }\end{array}$ & $\begin{array}{l}\text { Environmental Loading Ratio (ELR = total non-renewable } \\
\text { emergy (NMLS)/local renewable emergy(R)) indicates } \\
\text { pressure of the system on local environment. Higher } \\
\text { fraction of renewable emergy in total emergy use (\%R) will } \\
\text { as a measure of long term sustainability improve the } \\
\text { indicator. }\end{array}$ & $\begin{array}{l}\text { Min NMLS = Min ELR } \\
\text { (NMLS= local non- } \\
\text { renewable emergy, } \\
\text { purchased emergy } \\
\text { and emergy of } \\
\text { labour and services) }\end{array}$ \\
\hline
\end{tabular}

\section{Evaluation and ranking of model solutions}

In the final stage the solutions of the optimisation models were evaluated and compared according to the socioeconomic and emergy indicators of sector's performance listed and defined in Table 3.

The indicator values were normalised in a way to allow for their relative comparison to the reference performance in 2010, as shown in Formulae 2.

$$
N_{i}=P_{i} / P_{\mathrm{i} 2010} \quad i=1, \ldots p
$$

Where $N_{i}$ is a normalised and $P_{i}$ is an original value of the $i^{\text {th }}$ indicator and $P_{i 2010}$ the value of this indicator in a reference year 2010. Based on the total deviation from the reference values, each solution was positioned and ranked according to their overall socio-economic and emergy performance. 
Table 3

Socioeconomic and Emergy Indicators of Sector's Performance

\begin{tabular}{|c|c|c|c|}
\hline \multicolumn{2}{|c|}{ Socioeconomic indicators } & \multicolumn{2}{|c|}{ Emergy indicators } \\
\hline Income & Total income in the sector ${ }^{*}$ & Emergy use & Unit Emergy Value (UEV) * \\
\hline Production & Total production in the sector* & & Emergy Density (ED) ${ }^{*}$ \\
\hline Employment & Number of employed persons* & $\begin{array}{l}\text { Interaction } \\
\text { with local }\end{array}$ & $\begin{array}{l}\text { Emergy Yield Ratio (EYR) reflects the } \\
\text { system's ability for exploitation of free local } \\
\text { resources }\end{array}$ \\
\hline $\begin{array}{l}\text { Public } \\
\text { payments } \\
\text { (PP) }\end{array}$ & Total amount of PP * & environment & Environmental Loading Ratio (ELR)* \\
\hline Income & Share of PP in total income * & System & $\begin{array}{l}\text { The share of renewable emergy in the tota } \\
\text { emergy use (\%R) }\end{array}$ \\
\hline \multirow[t]{2}{*}{ stability } & Hourly wage * & sustainability & \multirow{2}{*}{$\begin{array}{l}\text { Emergy Sustainability Index (ESI) is a ratio } \\
\text { between the sector's ability to exploit local } \\
\text { resources and pressure of a system to local } \\
\text { environment }\end{array}$} \\
\hline & $\begin{array}{l}\text { Income sufficiency is a share of } \\
\text { work that is fully paid with } \\
\text { income earned (PP excl.) }\end{array}$ & & \\
\hline $\begin{array}{l}\text { Environment } \\
\text { al impact }\end{array}$ & $\begin{array}{l}\text { Greenhouse gas emissions } \\
(\mathrm{GHG})^{*}\end{array}$ & $\begin{array}{l}\text { Emergy } \\
\text { exchange }\end{array}$ & \multirow{2}{*}{$\begin{array}{l}\text { Emergy exchange ratio(EER) unveils the } \\
\text { relative trade advantage in emergy } \\
\text { exchange(producer vs. purchaser) }\end{array}$} \\
\hline & GHG per unit of production * & & \\
\hline
\end{tabular}

"More in detail described in Table 2

\section{Results and Discussion}

Figure 2 shows farm type representation in the total dairy production according to the results of single-criterion optimisation model solutions (optimisation criteria listed in Table 2). Due to higher relevance of the solutions that pursue sector-level targets the figure solely presents these. The results indicating structural differences of the sector when other farm-level optimisation objectives are pursued are discussed in the text and in quantified form fully presented in the Appendix A.

Figure 2

Farm Type Representation in the Dairy production Structure (sector level criteria)

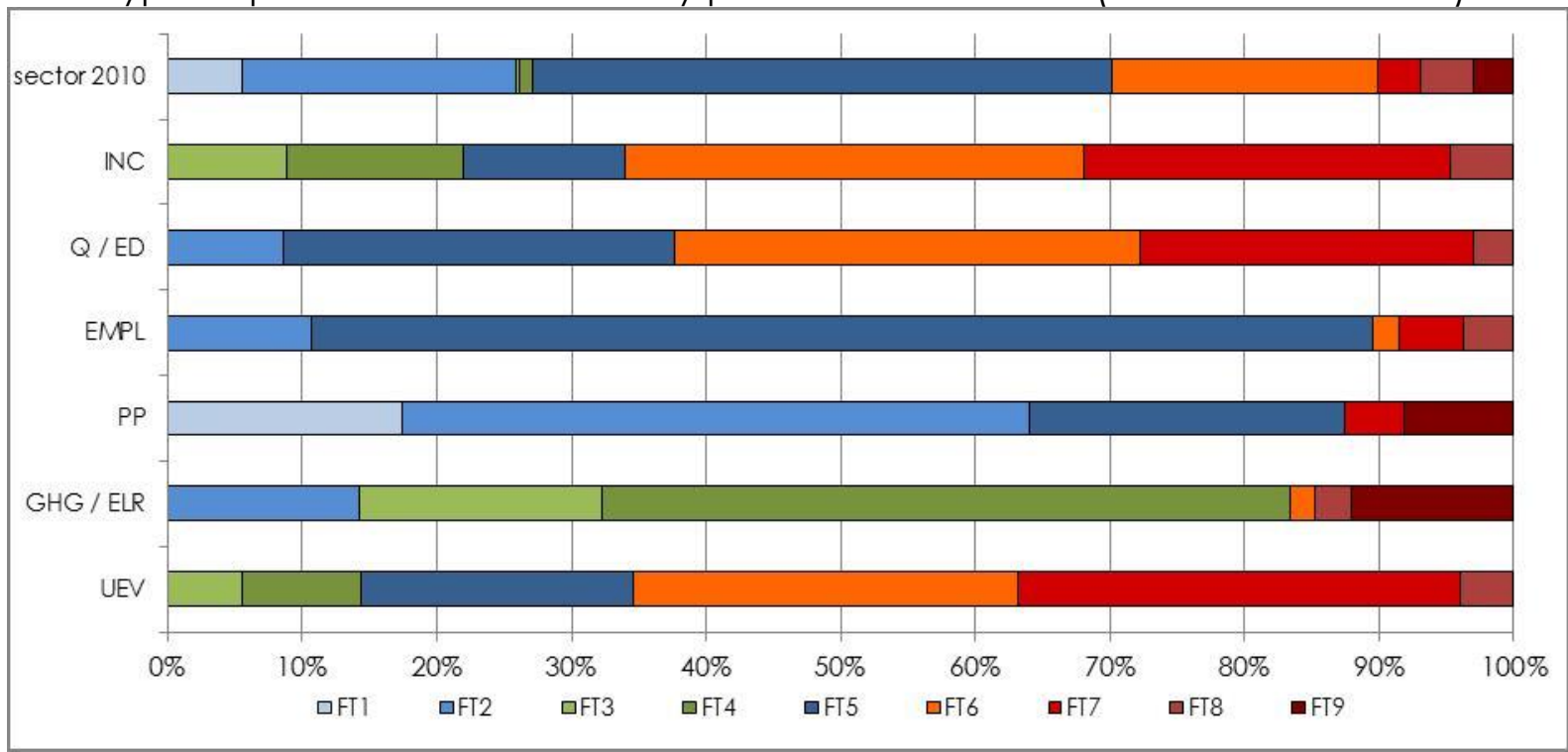

INC: income; Q: production; ED: Emergy density; EMP: employment; PP: public payments; GHG: greenhouse gas emissions; ELR: Environmental loading ratio; UEV: Unit emergy value Source: Author's illustration

The results show distinctive differences in the production structure when pursuing different objectives. In the reference year 2010 the production was distributed mainly 
to the production at smaller conventional farms (68.9\%) and partly to larger intensive farms $(29.9 \%)$, while the organic farms made an insignificant contribution to the total production $(1,2 \%)$. From the production structure of the alternative formulations of the sector three clusters of model solutions, categorised according to the share of organic production may be identified. First cluster includes the model solutions with relatively low or zero organic production. For example, further intensification of the sector, which would lead to highest possible productivity as well as emergy use intensity (Q / ED) may completely supplant organic production. Similar may happen in case where the focus lies solely on achieving high employment, lowest budgetary burden of the sector or lowest dependence of income on public payments. Contrary, the second group of model solutions may be identified by sector's significant reliance on organic production. These are the solutions that present the sector with lowest pressure on the global and local environment (GHG and ELR respectively) as well as the solution that reflects the sector with highest hourly wage $(\mathrm{HW})$. Finally, a relatively balanced production structure that encompasses a fair share of organic production as well as production based on conventional production technology at smaller, less intensive and larger, highly intensive farms can be recognised in model solutions that achieve highest income (INC) of the sector, highest biophysical efficiency (UEV) as well the solution that represent the production system with lowest GHG emission release per unit of production (GHG/q).

Figure 3 illustrates discrepancies in selected indicators measuring the performance of the dairy production system between the sector in 2010 and three scenarios of its reorganisation. The values presented are normalised and adjusted so that higher value indicates better performance.

Larger and even diametrical characteristics may be noted especially for the solutions pursuing highest productivity and the best environmental performance from the perspective of lowest emission release and lowest pressure on local environment. The results of the productivity-focused scenario show that the production structure that solely relies on conventional, mostly highly intensive production, markedly improves sector's productivity, biophysical efficiency, as well as income related criteria. However, such reorganisation of the sector that is based solely on conventional, mostly highly intensive production (Figure 2) is highly dependent on non-renewable resources $(96.5 \%)$, which harmfully affect the environment, both locally and globally, thus representing an evident step-back in terms of the system's sustainability.

Conversely, production planning that leads to restructuring of the sector that prioritises organic production, yields a sustainable production structure, characteristic for a relatively high share of renewable emergy used in the system (8.9\%), while the sector's pressure on local environment is low and its ability to exploit free local resources is high. However, this solution also brings unfavourable results in terms of a considerable productivity decrease and the corresponding knock-on effects on employment. Low productivity is also the vital reason for low environmental impact that is in relative terms (per unit of production) higher than the reference (sector in 2010).

Finally, the solution that targets the sector with highest income seems to emphasise the advantages and to reduce the weaknesses of the other two. Comparing to the sector in 2010 , it achieves considerably better results in most of the socio-economic and emergy based performance criteria, although at the expense of noticeably higher budgetary support and significantly lower employment in the sector. 
Figure 3

Discrepancies in Selected indicators describing performance of the dairy sector between the model solutions and the baseline (2010) situation

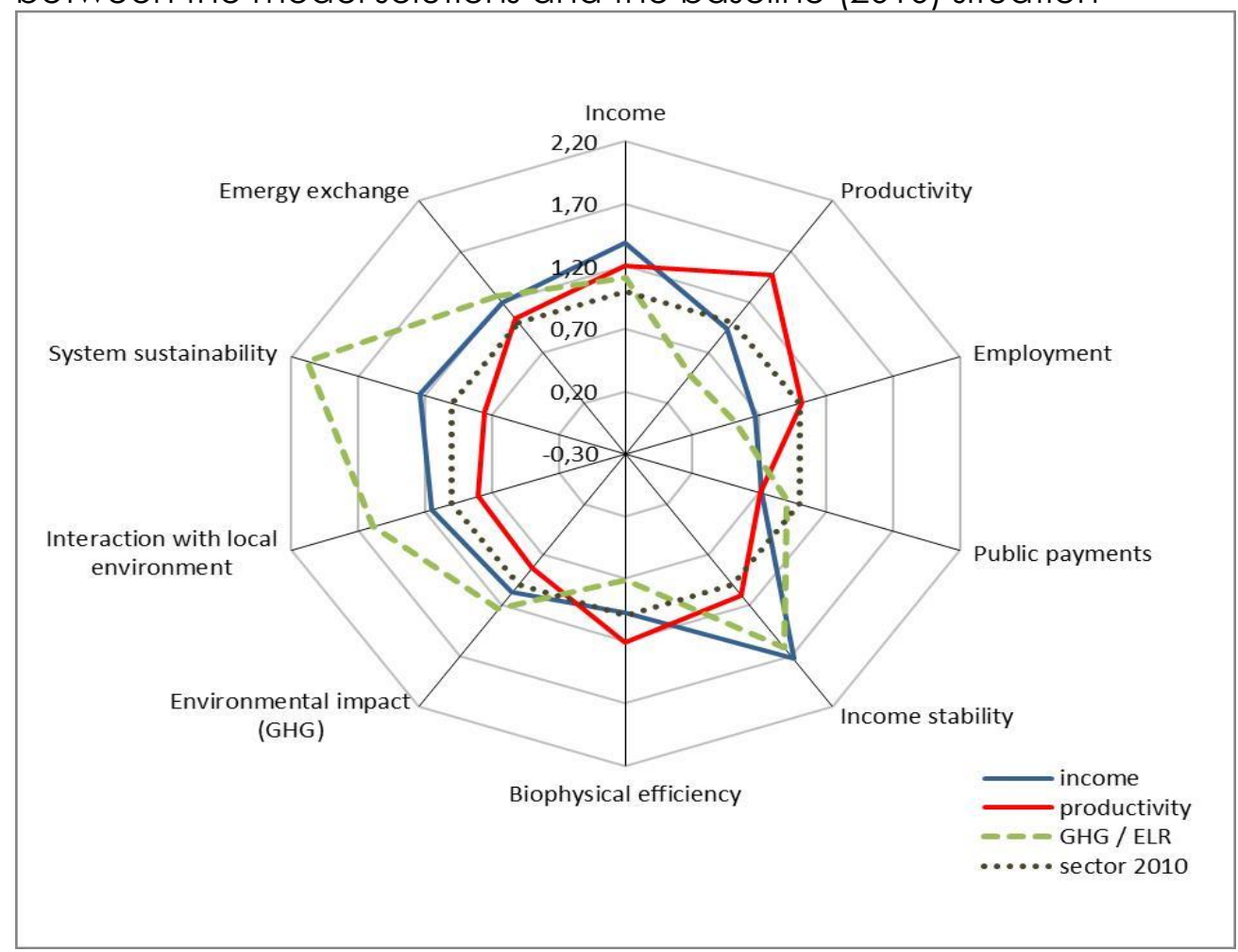

Source: Author's illustration

Figure 4

Classification and multiple-perspective position of model solutions with respect to their socio-economic and emergy performance.

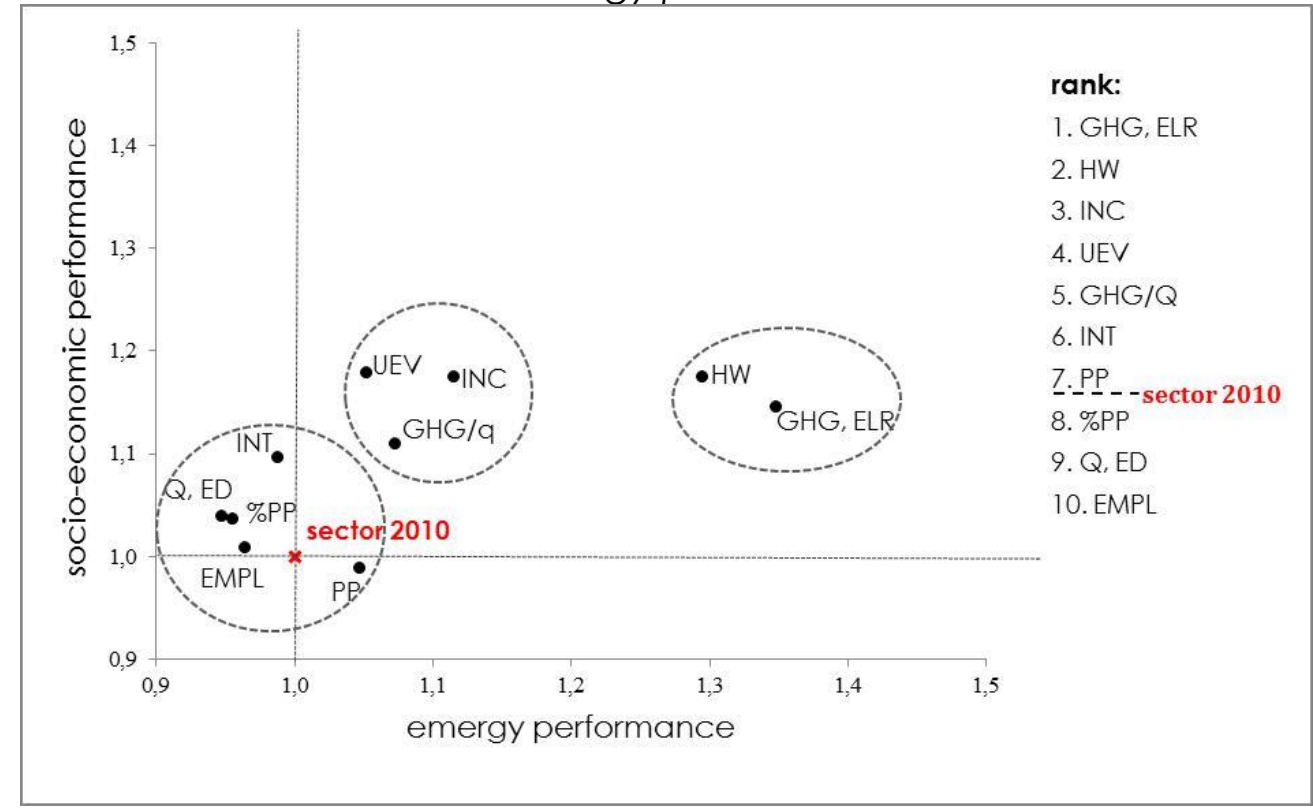

Source: Author's illustration

Furthermore, all of the model solutions were positioned and ranked according to their performance, illustrated by a set of socio-economic and emergy indicators. 
Again, illustrated in Figure 4, three clusters of model solutions can be noted. The results show that half of the solutions define the production system that is performing better that the reference sector from both, socio-economic and biophysical perspective. The solutions that represent the sector with lowest pressure on global and local environment as well as the solution with highest hourly wage in the sector are ranked the highest. This is contributed to their significant emergy performance that results from sector's strong orientation to organic production.

Similarly, reorganisations of the sector that achieves highest income, highest biophysical efficiency or lowest emission release per unit of production further highlights the possibilities to sector's overall improvement though pursuing a well balances production structure of the sector.

On the other hand, the rest of the model solutions represent production systems that perform better than the reference either from socio-economic or biophysical perspective. The solution representing the sector with highest intensity of production and the solution with lowest budgetary burden are performing slightly better than sector in 2010 when the whole set of ranking criteria is considered. However, the first one is ranked higher due to a notably better socio-economic position and the second due to its better biophysical functioning. Lowest ranking forms of sector's reorganisation are presented in model solutions pursuing lowest share of public payments in total income, highest productivity or emergy use intensity and finally highest employment in the sector. Although these solutions represent the sector with slightly better socio-economic characteristics than the sector in 2010, this does not weights out their poor biophysical functioning and ranks them even below the sector in 2010.

\section{Conclusion}

The main innovation aspect of this paper is incorporation of emergy analysis into the conventional production planning models in agriculture. By incorporating both, an economic (anthropocentric) and emergy based (eco-centric) indicators, the multiple-perspective model aims to provide more comprehensive evaluation of the sector's performance and of various alternatives to its reorganisation.

The results presented in the paper underline that joint application of emergy and economic criteria to the sector's optimisation brings mutually reinforcing results. The results underline the link between the intensification of production and the sector's overall improvement. Moreover, solutions suggesting a wide and diverse range of agricultural holdings with a balanced production structure are leading us to the conclusion that improvement of both, socio-economic and biophysical performance of the sector can be achieved even by pursuing only socio-economic objectives. However, the results clearly propose that representation of organic production plays a substantial role in such improvements.

The proposed approach has a major drawback in terms of the applicability of the results. Namely, the model is simplified in a manner that does not allow for reallocation of resources between various agricultural sectors. To our judgement, the shortcomings of this simplification can be circumvented by extending the modelling tool to other sectors competing for the same resources. However, this would demand substantial additional resources. Moreover, the results of single-criteria model solutions clearly show larger discrepancies in model solutions when different objectives are pursued. Since agricultural planning at the sector level is multiplecriterial in its nature, we see a great potential for the model improvement in developing a multiple-criteria optimisation modelling approach. Multiple-criteria 
analysis supported by goal programming or similar methodology could provide a better insight into the complexity of agricultural planning and therefore into possibilities of finding a compromise between conflicting objectives in decisionmaking processes.

\section{References}

1. Brown, M.T., Ulgiati, S., 2004. Emergy analysis and environmental accounting. Encyclopedia Energy 2, 329-354.

2. Brown, M.T., Ulgiati, S. 2010. Updated evaluation of exergy and emergy driving the geobiosphere: A review and refinement of the emergy baseline. Ecol. Model. 221, 2501-2508.

3. Chen G. Q., Jiang M. M., Chen B., Yang Z. F., Lin C. 2006. Emergy analysis of Chinese agriculture. Agriculture, Ecosystems \& Environment, 115, 1-4: 161-173

4. Castellini C., Bastianoni S., Granai C., Dal Bosco A., Brunetti M. 2006. Sustainability of poultry production using the emergy approach: Comparison of conventional and organic rearing systems. Agriculture, Ecosystems \& Environment, 114: 343350

5. Daily G. C., Söderqvist T., Aniyar S., Arrow K., Dasgupta P., Ehrlich P. R., Folke C., Jansson A., Jansson B., Kautsky N., Levin S., Lubchenco J., Maler K. G., Simpson D., Starrett D., Tilman D., Walker B. 2000. The value of nature and the nature of value. Science, 289: 395-396

6. de Barros I., Blazy J. M., Rodrigues G. S., Tournebize R., Cinna J. P. 2009. Emergy evaluation and economic performance of banana cropping systems in Guadeloupe (French West Indies). Agriculture, Ecosystems \& Environment, 129, 4: 437-449

7. Flichman G., Allen T. 2012. Bio-economic modeling: State-of-the-art and key priorities. CGIAR, Research Program on Policies, Instritutions and Markets.

8. http://www.pim.cgiar.org/files/2013/12/FlichmanThomas_BioEconModeling_Final .pdf

9. Gasparatos A., El-Haram M., Horner M. 2009. The argument against a reductionist approach for measuring sustainable development performance and the need for methodological pluralism. Accounting Forum, 33, 3: 245-256

10. Gasparatos A., Scolobig A. 2012. Choosing the most appropriate sustainability assessment tool. Ecological Economics, 80: 1-7

11. Godfray H., Charles J., Beddington J. R., Crute I. R., Haddad L., Lawrence D., Muir J. F., Pretty J., Robinson S., Thomas S. M., Toulmin C. 2010. Food security: the challenge of feeding 9 Billion people. Science, 327: 812-818

12. Ghisellini P., Zucaro A., Viglia S., Ulgiati S. 2014. Monitoring and evaluating the sustainability of Italian agricultural system. An emergy decomposition analysis. Ecological Modelling, 271: 132-148

13. Hu Q. H., Zhang L. X., Wang C. B. 2012. Emergy-based analysis of two chicken farming systems: a perception of organic production model in China. Procedia Environmental Sciences, 13: 445-454

14. Jaklič T., Juvančič L., Kavčič S., Debeljak M. 2014. Complementarity of socioeconomic and emergy evaluation of agricultural production systems: The case of Slovenian dairy sector. Ecological Economics, 107: 469-481

15. La Rosa A. D., Siracusa G., Cavallaro R. 2008. Emergy evaluation of Sicilian red orange production. A comparison between organic and conventional farming. Journal of Cleaner Production, 16, 17: 1907-1914

16. Lefroy E., Rydberg T. 2003. Emergy evaluation of three cropping systems in southwestern Australia. Ecological Modelling, 161: 193-209 
17. Li Q., Yan Q. 2012. Assessing the health of agricultural land with emergy analysis and fuzzy logic in the major grain-producing region. CATENA, 99: 9-17

18. LU H. F., Baib Y., Rena H., Campbell D. E. 2010. Integrated emergy, energy and economic evaluation of rice and vegetable production systems in alluvial paddy fields: Implications for agricultural policy in China. Journal of Environmental Management, 91, 12: 2727-2735

19. Odum H. T. 1983. Systems Ecology: An Introduction. New York, John Wiley: 644 pp.

20. Odum H. T. 1988. Self-organization, transformity, and information. Science, 242: $1132-1139$

21. Odum H. T. 1996. Environmental accounting. Energy and environmental decision making. New York, John Wiley \& Sons, 370 pp.

22. OECD. 2000. Environmental Indicators for Agriculture. Methods and Results. Executive Summary 2001. OECD Publishing: 53 pp.

23. OECD/FAO. 2012. OECD-FAO Agricultural Outlook 2012-2021. OECD Publishing and FAO: 286 pp.

24. Rydberg T., Haden A. C. 2006. Emergy evaluations of Denmark and Danish agriculture: Assessing the influence of changing resource availability on the organization of agriculture and society. Agriculture, Ecosystems \& Environment, 117: 145-158

25. Smith C. A. S., McRae T. 2000. Understanding and Assessing the Environmental Sustainability of Agriculture. V: Environmental Sustainability of Canadian Agriculture: Report of the Agri Environmental Indicator Project. A Summary. MCRae, T., Smith, C.A.S., Gregorich L.J. (eds.). Ottava, Agriculture and Agri-Food Canada: 2

26. van Zanten B. T., Verburg P. H., Espinosa M., Gomez-y-Paloma S., Galimberti G., Kantelhardt J., Kapfer M., Lefebvre M., Manrique R., Piorr A., Raggi M., Schaller L., Targetti S., Zasada I., Viaggi D. 2014. European agricultural landscapes, common agricultural policy and ecosystem services: a review. Agronomy for Sustainable Development, 34, 2: 309-325

27. Vigne M., Peyraud J., Lecomte P., Corson M., Wilfart A. 2013. Emergy evaluation of contrasting dairy systems at multiple levels. Journal of Environmental Management, 129: 44-53 


\section{About the authors}

Tina Kocjančič holds a PhD in Biosciences (Economics of natural resources) and works as researcher at the Biotechnical Faculty of the University of Ljubljana. The main challenge of her research work is to merge economic and ecological aspects in the evaluation and organization of economic activities. She is developing new research approaches, combining standard economic and operation research tools with emergy analysis, which is her main field of expertise. Author can be contacted at tina.kocjancic@bf.uni-lj.si

Jaka Žgajnar holds a PhD in Agricultural Economics and is assistant professor at the Biotechnical Faculty of the University of Ljubljana. His main research filed is agriculture management applying different methods from the field of operation research. He deals also with risk management and income risk analysis, animal health economics and lately also with equinomics. Author can be contacted at jaka.zgajnar@bf.unilj.si

Luka Juvančič holds a in PhD Agricultural Economics and is associate professor of Agricultural and Resource economics and the Head of the Chair for Agricultural Economics, Policy and Law at the Biotechnical Faculty of the University of Ljubljana. The range of his scientific interest and expertise spans from policy-oriented research (mainly dealing with various aspects of agricultural and rural development policies), to environmental and ecological economic research (eg. valuation of ecosystem services, biophysical valuation of economic activities), and to social science research (eg. political economy of agricultural policy, public perception and acceptance of GMO). Author can be contacted at luka.juvancic@bf.uni-lj.si 


\section{Appendix A Farm structure and performance characteristics of single-criterion model solutions}

\begin{tabular}{|c|c|c|c|c|c|c|c|c|c|c|c|}
\hline Optimisation criteria* & \multicolumn{2}{|c|}{$\underline{\underline{u}}$} & $\underset{1}{3}$ & $\begin{array}{l}\stackrel{\longrightarrow}{u} \\
\ddot{\sigma}\end{array}$ & $\underline{\underline{z}}$ & $\sum_{\Psi}^{\vec{n}}$ & $\frac{0}{2}$ & $\frac{0}{\frac{0}{0}}$ & 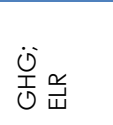 & $\begin{array}{l}\overline{0} \\
\stackrel{T}{0} \\
0\end{array}$ & 学 \\
\hline \multicolumn{12}{|l|}{ Farm structure unit } \\
\hline $\begin{array}{l}\text { number of farms in } \\
\text { the sector }\end{array}$ & num. & 6.264 & 6.085 & 5.772 & 5.340 & 7.277 & $\begin{array}{l}16.75 \\
9\end{array}$ & 6.826 & 6.716 & 6.057 & 5.796 \\
\hline share FTl & $\%$ & 0 & 0 & 0 & 0 & 0 & 62,62 & 0 & 0 & 24,81 & 0 \\
\hline share FT2 & $\%$ & 0 & 0 & 35,58 & 0 & 28,22 & 31,72 & 30,08 & 16,37 & 0 & 0 \\
\hline share FT3 & $\%$ & 65,81 & 67,75 & 0 & 35,09 & 0 & 0 & 0 & 65,14 & 20,87 & 52,13 \\
\hline share FT4 & $\%$ & 9,82 & 20,64 & 0 & 4,05 & 0 & 0 & 0 & 17,98 & 15,98 & 8,59 \\
\hline share FT5 & $\%$ & 9,75 & 10,04 & 40,33 & 34,81 & 69,77 & 5,37 & 63,07 & 0 & 30,69 & 21,08 \\
\hline share FT6 & $\%$ & 8,95 & 0 & 15,54 & 16,8 & 0,55 & 0 & 0 & 0,24 & 0 & 9,68 \\
\hline share FT7 & $\%$ & 5,12 & 0,36 & 7,97 & 8,61 & 0,99 & 0,24 & 6,74 & 0 & 7,59 & 7,93 \\
\hline share FT8 & $\%$ & 0,54 & 1,21 & 0,59 & 0,63 & 0,47 & 0 & 0,06 & 0,15 & 0 & 0,58 \\
\hline share FT9 & $\%$ & 0 & 0 & 0 & 0 & 0 & 0,04 & 0,05 & 0,11 & 0,07 & 0 \\
\hline \multicolumn{12}{|c|}{ Performance indicators } \\
\hline \multicolumn{12}{|c|}{ Socio-economic performance indicators } \\
\hline Income & $000 €$ & 127.490 & $\begin{array}{l}107.57 \\
5\end{array}$ & 110.551 & $\begin{array}{l}119.99 \\
4\end{array}$ & 93.610 & 79.679 & 98.177 & 101.195 & 106.638 & 125.193 \\
\hline Production & $\dagger$ & 561.78 & 335.54 & 886.33 & 806.34 & 713.68 & 425.86 & 791.87 & 285.44 & 584.373 & 668.50 \\
\hline Employment & pers. & 5.622 & 4.593 & 8.559 & 7.296 & 9.572 & 8.197 & 9.227 & 4.383 & 6.279 & 6.325 \\
\hline $\begin{array}{l}\text { Public payments } \\
\text { (PP) }\end{array}$ & $000 €$ & 66.069 & 59.368 & 66.887 & 70.023 & 52.629 & 39.873 & 54.712 & 56.594 & 58.869 & 66.743 \\
\hline $\begin{array}{l}\text { Share of PP in total } \\
\text { revenues }\end{array}$ & $\%$ & 18,00 & 21,10 & 14,30 & 15,50 & 13,90 & 14,7 & 13,3 & 21,80 & 16,5 & 16,60 \\
\hline Income sufficiency & & 0,64 & 0,62 & 0,30 & 0,40 & 0,25 & 0,29 & 0,28 & 0,60 & 0,45 & 0,54 \\
\hline $\begin{array}{l}\text { Greenhouse gas } \\
\text { emissions (GHG) }\end{array}$ & $\begin{array}{l}\text { teq } \\
\mathrm{CO}_{2}\end{array}$ & 655.616 & $\begin{array}{l}407.64 \\
4\end{array}$ & $\begin{array}{l}1.019 .54 \\
3\end{array}$ & $\begin{array}{l}921.47 \\
4\end{array}$ & $\begin{array}{l}835.70 \\
7\end{array}$ & $\begin{array}{l}549.59 \\
7\end{array}$ & $\begin{array}{l}896.19 \\
6\end{array}$ & 360.843 & 651.302 & 762.873 \\
\hline $\begin{array}{l}\text { GHG per unit of } \\
\text { production }\end{array}$ & $\begin{array}{l}\text { teq } \\
\mathrm{CO}_{2} / \mathrm{t}\end{array}$ & 1,17 & 1,21 & 1,15 & 1,14 & 1,17 & 1,29 & 1,13 & 1,26 & 1,11 & 1,14 \\
\hline Emergy indicators & & & & & & & & & & & \\
\hline Unit emergy value & & 1,54 & 1,77 & 1,56 & 1,53 & 1,68 & 2,02 & 1,62 & 1,89 & 1,6 & 1,53 \\
\hline Emergy density & & 208,1 & 142,01 & 331,49 & 295,35 & 288,09 & 205,98 & 306,96 & 129,04 & 223,98 & 244,51 \\
\hline Emergy yield ratio & & 1,09 & 1,13 & 1,06 & 1,07 & 1,07 & 1,09 & 1,07 & 1,15 & 1,09 & 1,08 \\
\hline $\begin{array}{l}\text { Environmental } \\
\text { loading ratio }\end{array}$ & & 17,12 & 11,36 & 27,86 & 24,72 & 24,08 & 16,93 & 25,73 & 10,23 & 18,5 & 20,29 \\
\hline $\begin{array}{l}\text { Emergy sustainability } \\
\text { index }\end{array}$ & & 0,06 & 0,1 & 0,04 & 0,04 & 0,04 & 0,06 & 0,04 & 0,11 & 0,06 & 0,05 \\
\hline $\begin{array}{l}\text { Fraction of } \\
\text { renewable emergy }\end{array}$ & & 0,06 & 0,08 & 0,03 & 0,04 & 0,04 & 0,06 & 0,04 & 0,09 & 0,05 & 0,05 \\
\hline $\begin{array}{l}\text { Emergy exchange } \\
\text { ratio }\end{array}$ & & 1,11 & 1,03 & 1,33 & 1,25 & 1,42 & 1,43 & 1,39 & 1,02 & 1,21 & 1,17 \\
\hline
\end{tabular}

* INC: income; HW: hourly wage; Q: production; INT: intensity of production; EMP: employment; PP: public payments; \%PP: share of PP in total revenues; GHG: greenhouse gas emissions, GHG/Q: GHG per unit of production; ED: Emergy density; UEV: Unit emergy value, ELR: Environmental loading ratio 